\title{
Plant functional traits and microbes vary with position on striped periglacial patterned ground at Glacier National Park, Montana
}

\author{
APPLE Martha Elizabeth ${ }^{1}$, RICKETTS Macy Kara², MARTIN Alice Caroline ${ }^{3}$ \\ 1. Department of Biological Sciences, Montana Technological University, Butte, Montana 59701, USA; \\ 2. Department of Botany, The University of Wyoming, Laramie, Wyoming 82071, USA; \\ 3. Division of Biological Sciences, The University of Montana, Missoula, Montana 59812, USA
}

\begin{abstract}
The retreating snowfields and glaciers of Glacier National Park, Montana, USA, present alpine plants with changes in habitat and hydrology. The adjacent and relic periglacial patterned ground consists of solifluction terraces of green, vegetation-rich stripes alternating with sparsely vegetated brown stripes. We established georeferenced transects on striped periglacial patterned ground for long-term monitoring and data collection on species distribution and plant functional traits at Siyeh Pass and at Piegan Pass at Glacier National Park. We documented species distribution and calculated the relative percent cover (RPC) of qualitative functional traits and used 16S rRNA from soil samples to characterize microbial distribution on green and brown stripes. Plant species distribution varied significantly and there were key differences in microbial distribution between the green and brown stripes. The rare arctic-alpine plants Draba macounii, Papaver pygmaeum, and Sagina nivalis were restricted to brown stripes, where the RPC of xeromorphic taprooted species was significantly higher at the leading edge of the Siyeh Pass snowfield. Brown stripes had a higher percentage of the thermophilic bacteria Thermacetogenium and Thermoflavimicrobium. Green stripes were co-dominated by the adventitiously-rooted dwarf shrubs Salix arctica and the possibly N-fixing Dryas octopetala. Green stripes were inhabited by Krummholz and seedlings of Abies lasiocarpa and Pinus albicaulus. Prosthecobacter, a hydrophilic bacterial genus, was more abundant on the green stripes, which had 6,524 bacterial sequences in comparison to the 1,183 sequences from the brown stripes. While further research can determine which functional traits are critical for these plants, knowledge of the current distribution of plant species and their functional traits can be used in predictive models of the responses of alpine plants to disappearing snowfields and glaciers. This research is important in conservation of rare arctic-alpine species on periglacial patterned ground.
\end{abstract}

Keywords: alpine plants; plant functional traits; microbes; periglacial patterned ground; climate change; Glacier National Park, Montana

Received: 2018-05-10 Accepted: 2019-01-22

Author: APPLE Martha Elizabeth, E-mail: MApple@mtech.edu 


\section{Introduction}

Alpine plants are sensitive to climate change (Gottfried et al., 2012; Pauli et al., 2012). The snowfields and glaciers of Glacier National Park, Montana, USA, are disappearing due to climate change (Pederson et al., 2010), which will likely have profound impacts on alpine plants that use glacial meltwater during the brief alpine summers (Vitasse et al., 2016; Björk and Molau, 2007). At Glacier National Park, plants grow on adjacent periglacial patterned ground, which formed as stripes from relic solifluction terraces and as polygons from relic stone nets (Butler and Malanson, 1999; Elias, 1996). Periglacial patterned ground is influenced by water availability (Matthews et al., 1998) and is subject to climate change (Cannone et al., 2004; Kade and Walker, 2008). Arctic-alpine plant species, some of which are rare, exist at the southern edge of their range in Glacier National Park where their populations are declining due to increased temperatures (Lesica and McCune, 2004). Baseline and long-term monitoring of periglacial patterned ground communities is essential for understanding the responses of alpine plants to shifts in habitat wrought by climate change and to generate data for predictive models of the fate of these plants when their icy homes have disappeared (Fagre et al., 2003; Laughlin et al., 2012; Valles et al., 2017).

Glacier National Park is an especially relevant site for monitoring since it has vast cultural and biological significance with vanishing glaciers that have attracted major interest (Fagre et al. 2017; Carey, 2007). The Waterton-Glacier International Peace Park, designated by UNESCO as a Man and Biosphere Reserve (MAB) in 1976 and as a World Heritage Site in 1995, consists of Glacier National Park and the adjacent Waterton Lakes National Park in Alberta, Canada.

Steep environmental gradients of the alpine zone contribute to the formation of microhabitats (Scherrer and Körner, 2011) and influence plant functional traits, which are characteristics of plants that govern their interactions with the environment (Cornwall and Ackerly, 2009). Alpine plants are exposed to harsh wind, cold and high temperatures, strong solar irradiation, changes in snow cover, shifting substrata, and gradients of water availability.

The distribution of soil microbes may play a key role in determining the distribution of plant species and functional traits (King et al., 2013). Seed-associated fungi can influence seedling recruitment and community composition through pathogenic effects on seeds and positive effects on seed germination and plant growth (Tobias et al., 2017). Bacteria can explain aspects of species distribution in models (Bueno de Mesquita et al., 2016).

Community weighted trait means (CWTMs) of plant functional traits are valuable in understanding community responses to zoogenic (Choler, 2005) and other disturbances (Mouillot et al., 2013). CWTMs are important in explaining patterns of spatial and temporal change in alpine snowfield habitats (Venn et al., 2011; 2014) and in community responses to climate change (McGill et al., 2006). CWTMs and relative percent cover (RPC) can be used to determine whether functional traits change with position on the relatively flat brown stripes and the sloping green stripes that run perpendicular to gentler slopes but parallel to steeper slopes on periglacial patterned ground at Glacier National Park.

Functional traits allow plants to respond to environmental conditions, which influence leaf development in alpine plants (Li et al., 2015). Dissected leaves dissipate photosystem-damaging heat (Creese et al., 2010; Buchner et al., 2015) and cushion morphology shields against drought and extreme temperatures (Cavieres et al., 2007). Xeromorphic traits include tap and 
adventitious roots, shrub morphology, low ratios of leaf surface to volume, wilt-resistant evergreen sclerophyllous leaves, and leaf rolling (De Micco and Aronne, 2012). Long-lived clonal plants can stabilize alpine grasslands and heaths (Grabherr, 2003; de Whitte and Stöcklin, 2010) and rhizomatous species can survive at $6100 \mathrm{~m}$ (Dvorsky et al., 2016).

The retreat of snowfields due to climate change will result in the loss or alteration of habitats for alpine plants (Lesica 2014: Hotaling et al., 2017) which can live for decades or even centuries (Forbis and Doak, 2004). Functional traits and the environment filter the distribution of alpine plants (Venn et al., 2011). It is important to monitor the distribution of alpine plants in light of habitat change wrought by retreating snowfields and glaciers (Hall and Fagre, 2003).

We established georeferenced transects on striped periglacial patterned ground of Glacier National Park to determine the current distribution of alpine plants and functional traits and to explore the distribution of alpine soil microbes. In addition, this research was conducted with the goal of establishing long-term monitoring sites as reference points and to increase our understanding of the responses of alpine plants to habitat change due to climate change.

\section{Materials and methods}

\subsection{Sites}

Georeferenced sites were established on trail-accessed striped periglacial patterned ground where rare arctic-alpine plants grow near currently extensive snowfields at Piegan Pass and Siyeh Pass east of the Continental Divide in the alpine zone of the Lewis Mountain Range of Glacier National Park, Montana, USA in 2014 (Figures 1 and 2). Three $50 \mathrm{~m}$ transects extended from the lateral and leading edges of the snowfields and perpendicularly to the striped patterned ground. The Piegan Pass lateral transects (PPSL) are at an elevation of $2335 \mathrm{~m}\left(+48.72037^{\circ} \mathrm{N},-113.688049^{\circ} \mathrm{W}\right)$. The Siyeh Pass lateral transects (SPSL) are at $2415 \mathrm{~m}\left(+48.718202^{\circ} \mathrm{N},-113.627278^{\circ} \mathrm{W}\right)$ and cross the snowfield's lateral moraine in the

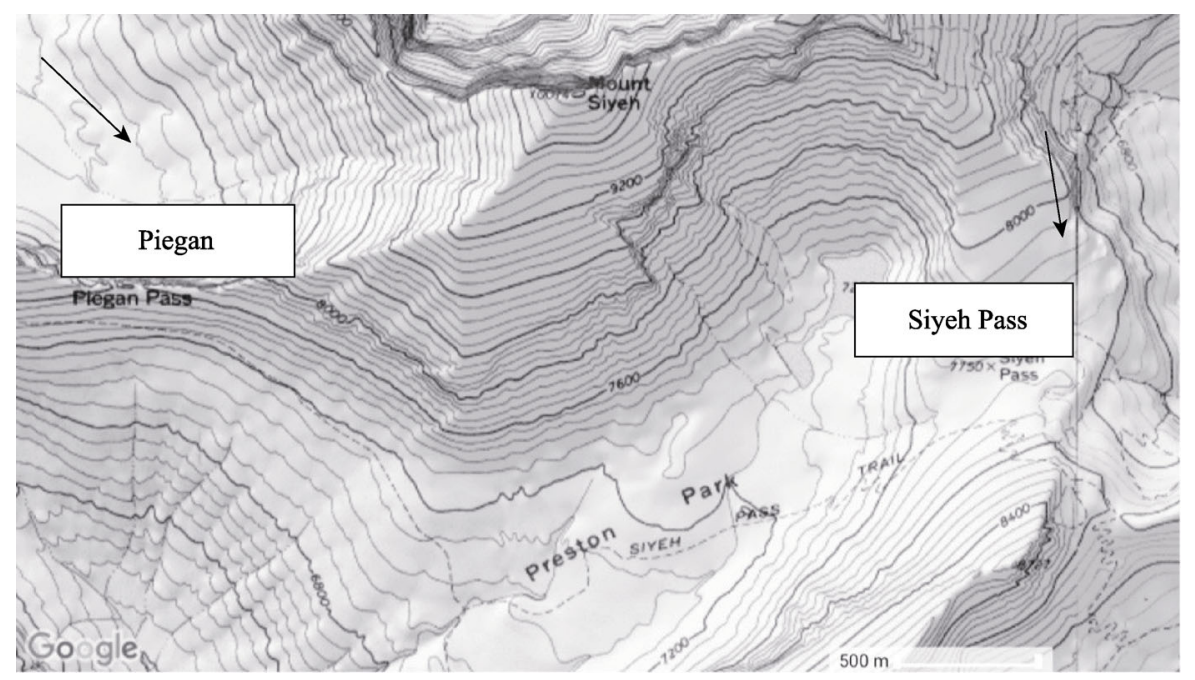

Figure 1 Google Earth Topographic Map of the Siyeh Pass and Piegan Pass snowfields at Glacier National Park, Montana 
first $10 \mathrm{~m}$ and descend gradually to intersect the patterned ground. The Siyeh Pass leading transects (SPST) are at $2362 \mathrm{~m}\left(+48.719139^{\circ} \mathrm{N},-113.627179^{\circ} \mathrm{W}\right)$ on an almost flat fellfield with a puddle of meltwater at the edge. The alpine areas of GNP have a Köppen climate designation of Dfc, which is a Continental Subarctic climate (Brugger, 2017).
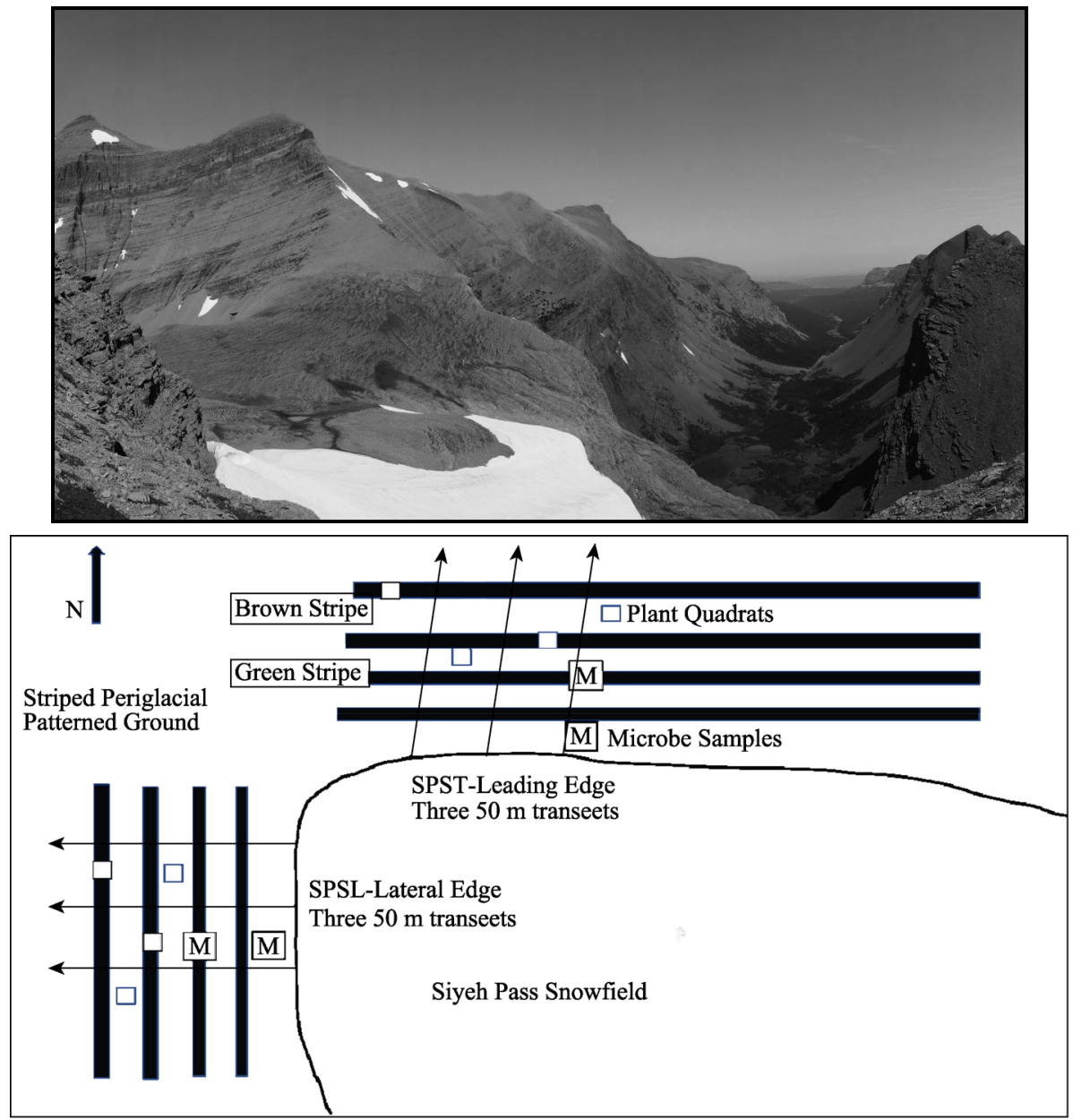

Figure 2 The Siyeh Pass Snowfield and adjacent periglacial patterned ground at Glacier National Park, Montana (above). Schematic diagram of sampling design (below).

\subsection{Sampling}

Eighty $1 \mathrm{~m} \times 1 \mathrm{~m}$ quadrats were placed and photographed along the transects on striped periglacial patterned ground. Of these, 20 were placed along the Siyeh Pass snowfield's leading transects (SPST), with 10 on the brown and 10 on the green stripes. Thirty quadrats were placed near the lateral edge of the Siyeh Pass snowfield (SPSL) with 15 on the brown and 15 on the green stripes. Thirty quadrats were placed near the lateral edge of the Piegan Pass (PPSL) snowfield with 15 on the brown and 15 on the green stripes. Quadrats were categorized as green with plant cover $\geqslant 70 \%$, and brown with plant cover $\leqslant 25 \%$. Species presence and richness, percent cover, and percent rock and scree were recorded. Other quadrats ( $n=20$, SPST; $n=19$ SPSL; $n=39$ PPSL) were examined for the presence of 
krummholz or tree seedlings.

\subsection{Soil microbes}

In 2016, soil samples were collected along similar $50 \mathrm{~m}$ transects at Siyeh and Piegan Passes. Three transects per site were sampled for a total of 180 samples with two, $2.0 \mathrm{~g}$ samples collected in microcentrifuge tubes every ten meters along each transect. Samples were immediately frozen on dry ice in the field and stored in the labat $-80^{\circ} \mathrm{C}$. DNA extraction for genomic analysis was performed with an MP BioLabsFastDNA SPIN Kit for Soil (MP Bio, 2017). Characterizations of $16 \mathrm{~S}$ rRNA were performed on six samples, with three from the brown and three from the green stripes. Although the microbiome of the entire study area was not represented by this sample size, it was useful in defining microbial differences between brown and green stripes.

PCR amplification of the DNA (MrDNA, Inc., Houston, Texas) used the 16S rRNA gene V4 variable region PCR primers 515 and 806. In a single-step, 30 cycle PCR machine, HotStarTaq Plus Master Mix Kit was mixed with each sample in PCR tubes at $94^{\circ} \mathrm{C}$ for three minutes followed by 28 cycles of $94^{\circ} \mathrm{C}$ for 30 seconds, $53^{\circ} \mathrm{C}$ for 40 seconds, $72^{\circ} \mathrm{C}$ for one minute, and $72^{\circ} \mathrm{C}$ for five minutes. Sequencing was performed with Ion Torrent PGM. The sequences were grouped into operational taxonomic units (OTUs), then classified using a three percent divergence. Final OTUs were classified with the BLASTn online database.

\subsection{Plant functional traits}

Qualitative functional traits were defined from field observations or the literature (Clawson et al., 2004; Cripps and Eddington, 2005; Lesica, 2002, 2012; Kohls et al., 2003; Markham, 2009; Pérez-Harguindeguy et al., 2013) and included taxonomic group, evergreen leaves, leaf shape, morphology, mycorrhizal and N-fixing symbioses, root type, clonality, and Raunkiaer classification (Raunkiaer, 1934). Qualitative traits were assigned a value of one if present and a zero if not. Relative percent cover was calculated by multiplying the percent cover of individual species by total vascular plant cover in a quadrat (Fortunel et al., 2009; Garnier et al., 2007; Sonneman et al., 2015). Relative percent cover values (RPC) for all species with a particular trait were added and divided by the total vascular plant cover per quadrat. The number of quadrats with rare plants was divided by the total number of quadrats for rare plant relative frequencies.

\subsection{Statistics}

Student's paired t-tests were used to test for significant differences in the RPC per quadrat per site of qualitative traits and of species on the brown and green stripes, with $p \leqslant 0.01$ chosen as the delineating point of significance over the higher value of $p \leqslant 0.05$ because of repeated t-tests from the same samples of plants, albeit for different traits. A Moran's $I$ test was used to determine negative or positive spatial autocorrelation of trait data (GeoDa Software, University of Chicago). Nonmetric multidimensional scaling (Austin, 2013) with an attribute list and interval transformation was used to visualize dissimilarities among the RPC of plant functional traits on brown and green stripes, with similar objects appearing closely on a nonmetric multidimensional scaling plot. A Shephard Diagram of the $\mathrm{R}^{2}$ fit and 
a stress value of the transformed versus the predicted proximities were generated. Student's paired t-tests and nonmetric multidimensional scaling were conducted with JMP Software, (SAS Institute, North Carolina, USA).

\section{Results and analysis}

\subsection{Distribution of species and plant functional traits}

Plant functional traits and species distribution differed significantly $(p<0.01)$ between brown and green stripes of the periglacial patterned ground at Glacier National Park (Table 1). Suites of co-occurring traits in plants representative of the brown or green stripes had positive spatial autocorrelations according to the Moran's $I$ test with values above zero. Because the same traits co-occurred on the same plants, autocorrelation was inherent in these plants.

Table 1 The relative percent cover of qualitative plant functional traits on brown and green striped periglacial patterned ground at the Siyeh Pass Leading Edge (SPST), ( $n=10$ brown, $n=10$ green), and at the Siyeh Pass (SPSL) and Piegan Pass (PPSL) Lateral Edges ( $n=15$ brown, $n=15$ green). Shading of the higher value in a pair represents t-tests with significant differences of $p \leqslant 0.01$ between brown and green stripes. VAM $=$ Vesicular arbuscular mycorrhizae.

\begin{tabular}{|c|c|c|c|c|c|c|}
\hline \multicolumn{7}{|c|}{ Average Relative Percent Cover $+/-$ Standard Error } \\
\hline & \multicolumn{2}{|c|}{ SPST } & \multicolumn{2}{|c|}{ SPSL } & \multicolumn{2}{|c|}{ PPSL } \\
\hline & Brown & Green & Brown & Green & Brown & Green \\
\hline Rare Species & $9.3 \pm 2.0$ & $0.19 \pm 0.09$ & $29.7 \pm 0.3$ & $0.25 \pm 0.50$ & $3.3 \pm 1.2$ & $0.07 \pm 0.02$ \\
\hline Phanerophyte & 0 & 0 & 0 & 0 & 0 & $3.7 \pm 0.4$ \\
\hline Hemicryptophyte & $86.9 \pm 3.1$ & $13.5 \pm 1.8$ & $91.7 \pm 19.0$ & $50.3 \pm 3.9$ & $72.0 \pm 3.7$ & $18.2 \pm 1.7$ \\
\hline Chamaephyte & $15.7 \pm 4.3$ & $86.9 \pm 1.5$ & 0 & $48.2 \pm 3.7$ & $17.6 \pm 3.7$ & $67.1 \pm 1.4$ \\
\hline Cushion & $22.4 \pm 8.2$ & $1.8 \pm 0.3$ & $30.7 \pm 4.1$ & $26.5 \pm 2.6$ & $7.4 \pm 2.4$ & $4.3 \pm 8.9$ \\
\hline Mat & $29.2 \pm 7.5$ & $87.3 \pm 0.8$ & $0.36 \pm 3.2$ & $55.9 \pm 3.2$ & $45.2 \pm 4.1$ & $74.4 \pm 1.5$ \\
\hline Rosette & $4.5 \pm 2.5$ & $1.4 \pm 0.9$ & $3.1 \pm 3.7$ & $0.5 \pm 0.1$ & $3.4 \pm 0.9$ & $0.8 \pm 0.3$ \\
\hline Evergreen & $6.8 \pm 2.4$ & $69.6 \pm 5.2$ & 0 & $43.2 \pm 3.5$ & $12.1 \pm 3.2$ & $54.0 \pm 3.0$ \\
\hline Simple Leaves & $75.4 \pm 3.9$ & $92.4 \pm 1.2$ & $61.6 \pm 3.5$ & $90.6 \pm 1.4$ & $97.5 \pm 2.2$ & $97.7 \pm 3.5$ \\
\hline Lobed Leaves & $7.3 \pm 1.6$ & $0.7 \pm 0.2$ & $22.3 \pm 3.1$ & 0 & $2.3 \pm 0.6$ & $0.5 \pm 0.1$ \\
\hline Clonality & $56.3 \pm 4.3$ & $92.6 \pm 1.8$ & $64.1 \pm 1.6$ & $96.3 \pm 4.8$ & $75.0 \pm 2.9$ & $81.6 \pm 1.5$ \\
\hline Adventitious Roots & $49.5 \pm 6.3$ & $90.9 \pm 1.6$ & 0 & $48.2 \pm 3.7$ & $17.9 \pm 3.8$ & $69.6 \pm 1.4$ \\
\hline Rhizomes & $32.1 \pm 8.2$ & $4.7 \pm 0.3$ & $88.6 \pm 1.2$ & $51.7 \pm 3.7$ & $76.8 \pm 3.6$ & $18.5 \pm 1.4$ \\
\hline Taproots & $31.9 \pm 7.3$ & $2.1 \pm 0.9$ & $58.2 \pm 4.0$ & $31.2 \pm 3.7$ & $35.4 \pm 2.5$ & $10.7 \pm 1.2$ \\
\hline Woody roots & $15.7 \pm 4.3$ & $86.9 \pm 1.5$ & 0 & 0 & $30.7 \pm 8.3$ & $2.6 \pm 1.7$ \\
\hline Fibrous roots & $3.1 \pm 1.7$ & $0.1 \pm 0.1$ & $19.2 \pm 1.4$ & $3.1 \pm 6.8$ & $3.3 \pm 0.1$ & $0.4 \pm 0.1$ \\
\hline Nitrogen fixers & $14.4 \pm 3$ & $74.7 \pm 4.8$ & $0.5 \pm 0.1$ & $85 \pm 1.2$ & $7.6 \pm 2.8$ & $26.5 \pm 2.8$ \\
\hline All Mycorrhizae & $62.2 \pm 5.9$ & $93.1 \pm 0.3$ & $20.7 \pm 2.2$ & $78.7 \pm 5.6$ & $40.7 \pm 6.3$ & $80.0 \pm 4.2$ \\
\hline VAM & $47.1 \pm 5.6$ & $7.4 \pm 1.7$ & $19.6 \pm 2.0$ & $37.3 \pm 3.9$ & $21.8 \pm 3.5$ & $29.4 \pm 2.8$ \\
\hline Ectomycorrhizae & $20.0 \pm 4.8$ & $86.4 \pm 2.1$ & $12.3 \pm 4.1$ & $45.7 \pm 4.4$ & $16.4 \pm 3.3$ & $58.5 \pm 4.4$ \\
\hline
\end{tabular}


Species richness per quadrat did not differ significantly between brown $(8.50 \pm 1.07)$ and green stripes $(8.40 \pm 0.45)$. Eight species were restricted to the brown stripes: Draba macounii (Brassicaceae), Epilobium anagalidifolium (Onagraceae), Erigeron compositus (Asteraceae), Minuartia rubella (Carophyllaceae), Papaver pygmaeum (Papaveraceae), Phacelia lyallii (Hydrophyllaceae), Sagina nivalis(Caryophyllaceae), and Stellaria americana (Caryophyllaceae). Six species were restricted to the green stripes: Abies lasiocarpa (Pinaceae), Castilleja occidentalis (Orobanchaceae), Erigeron peregrinus (Asteraceae), Pedicularis contorta (Orobanchaceae), Pinus albicaulis (Pinaceae), and Phyllodoce glandiflora (Ericaceae).

Rare arctic-alpine plant species had significantly greater relative frequencies on brown stripes (Figure 3). All six were hemicryptophytes, herbaceous, $<10 \mathrm{~cm}$ tall, perennial dicots. The rare species restricted to the brown stripes were Draba macounii, Papaver pygmaeum, and Sagina nivalis. D. macounii has a branched rootcrown, a small loose cushion, and nearly glabrous foliage. P. pygmaeum is taprooted with basal leaves, stiff hairs and milky sap, and $S$. nivalis is taprooted with a small rosette.

Aquilegia jonesii (Ranunculaceae), Erigeron lanatus, and Phacelia lyallii were found on the brown and the green stripes. A. jonesii is taprooted and forms loose cushions with basal leaves, E. lanatus has a branched caudex and ascending stems with basal and alternate leaves, and $P$. lyallii has ascending stems and a taproot. No rare arctic-alpine species were restricted to the green stripes.

The mechanisms of clonality differed between brown and green stripes. Adventitiously- rooted species had significantly greater RPC on green stripes while rhizomatous species had significantly greater RPC on brown stripes (Figure 4). The RPC of clonal species was significantly greater on the brown stripes of SPST.

Plant and leaf morphology differed significantly. The RPC was significantly greater for hemicryptophytes on brown stripes and for chamaephytes on green stripes. Cushion plants had a significantly greater RPC on brown stripes at SPST but not at SPSL, where they grew with $D$. octopetala on green stripes. Lobed leaves had significantly

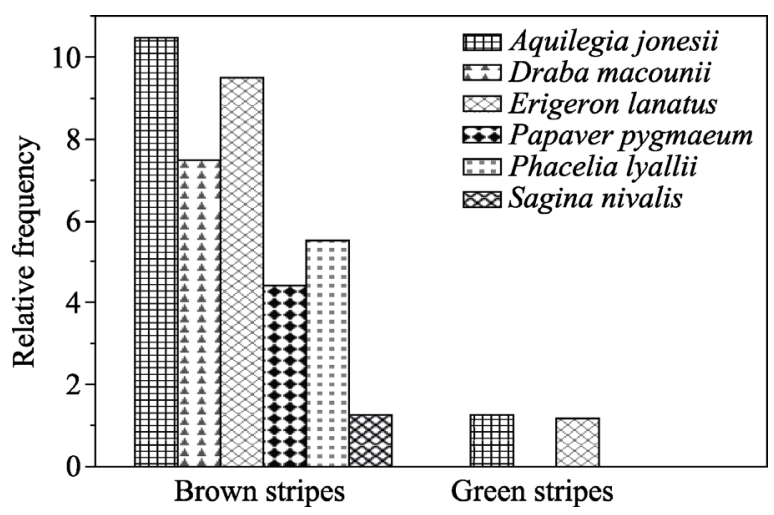

Figure 3 The relative frequency of rare arctic-alpine species on brown and green stripes of periglacial patterned ground at Siyeh Pass and Piegan Pass at Glacier National Park

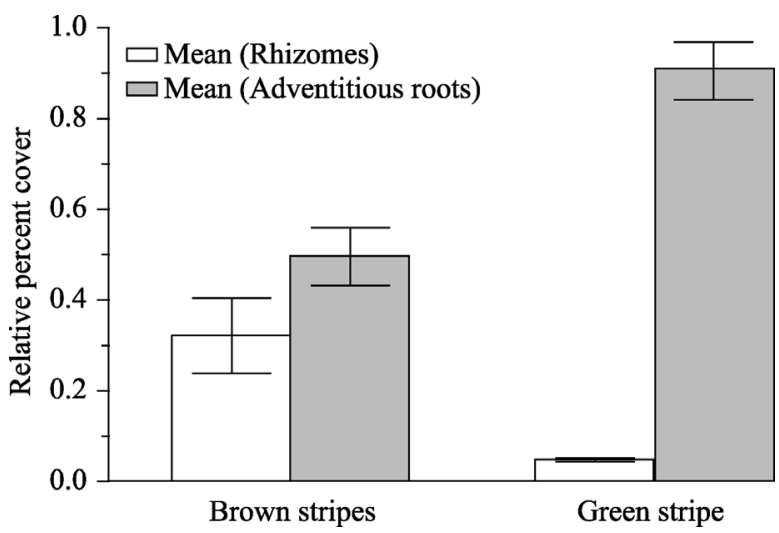

Figure 4 The relative percent cover of rhizomatous and adventitiously-rooted species (mean $+/-$ standard error) on brown and green stripes of periglacial patterned ground at Siyeh Pass and Piegan Pass at Glacier National Park 
greater RPC on brown stripes at SPST and SPSL but not PPSL, while simple leaves had significantly greater RPC on the green stripes of SPST and SPSL. Evergreen leaf RPC was significantly greater on the green stripes.

Underground symbioses differed with site and position on periglacial patterned ground. Vesicular arbuscular mycorrhizal plants had significantly greater RPC on the SPST brown stripes while ectomycorrhizal plants had significantly greater RPC on the green stripes at SPST and SPSL. The significantly greater mycorrhizal RPC at the SPST green stripes reflected the high RPC of ectomycorrhizal dwarf shrubs.

The dominance of Dryas octopetela and Salix arctica on green stripes drives the significantly greater RPC of their functional traits. These dicotyledonous, mat-forming, clonal and adventitiously-rooted dwarf shrubs are chamaephytes with ectomycorrhizal woody roots. While both have simple leaves, D. octopetela is evergreen. D. octopetala is symbiotic with $\mathrm{N}$-fixing Frankia species, and its dominance likely influences the nitrogen dynamics of green stripes and of the patterned ground in general. The combined RPC for Fabaceae and $D$. octopetala was significantly greater on the green stripes at SPST and SPSL, although the Fabaceae grew on both colors of stripes.

Krummholz and seedlings of conifers grew on the green stripes of SPSL and PPSL but not at SPST. At SPSL, Abies lasiocarpa, the subalpine fir, was present in 8 of 19 green

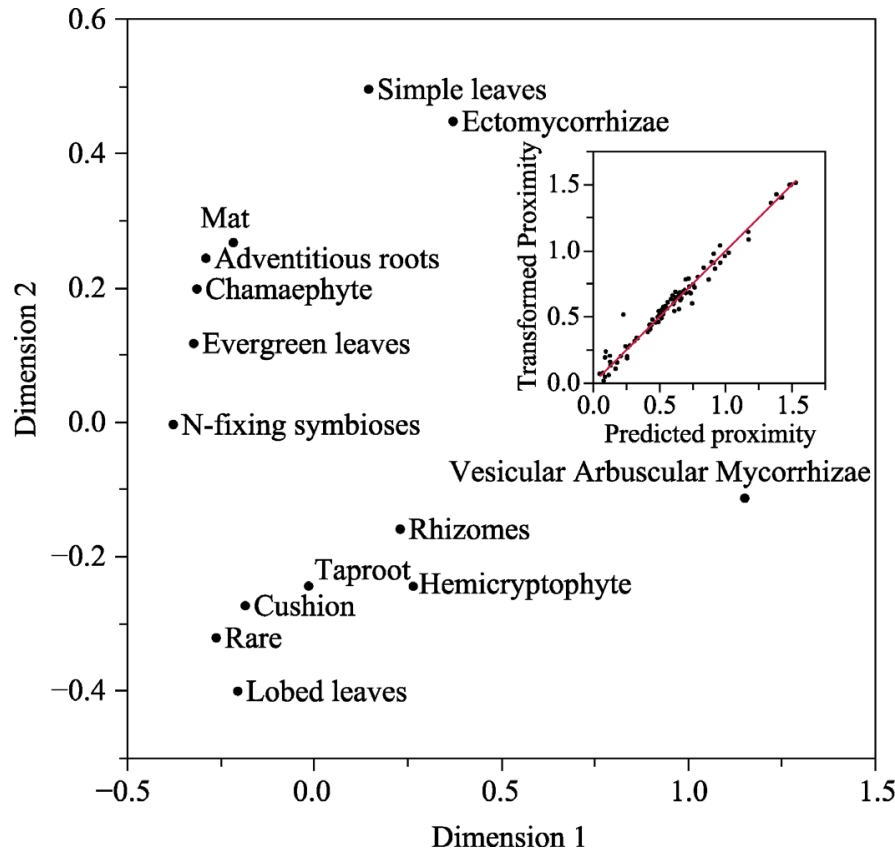

Figure 5 Multidimensional Scaling Plot of the relative percent cover of plant functional traits on striped periglacial patterned ground. The upper seven traits (Chamaephyte, Mat, Evergreen Leaves, Simple Leaves, Adventitious Roots, N-fixing symbioses, and Ectomycorrhizae) correspond with green stripes and the lower seven traits (Rare Species, Hemicryptophyte, Cushion, Lobed Leaves, Rhizomes, Taproots, and Vesicular Arbuscular Mycorrhizae) correspond with brown stripes. Details of fit are stress $=0.075$, and $\mathrm{R}^{2}=$ 0.977 (in the inset Shepard Diagram). stripes (42\%). At PPSL, $A$. lasiocarpa was present in 4 of 39 green stripes (23\%), with Pinus albicaulis, the whitebark pine, present in 5 $(12.8 \%)$ green stripes.

Multidimensional scaling of the RPC of functional traits on brown and green stripes yielded two groups of similarities with a good fit (low stress value of $0.075, \mathrm{R}^{2}$ $=0.977$ (Figure 5). One group consisted of traits predominating on the green stripes: chamaephytes, mats, evergreen leaves, simple leaves, adventitious roots, $\mathrm{N}$-fixing symbioses, and ectomycorrhizae. The other group consisted of traits predominating on the brown stripes: rarity, hemicryptophytes, cushions, lobed leaves, rhizomes, taproots, and vesicular arbuscular mycorrhizae. 


\subsection{Microbes of periglacial patterned ground}

The common soil microbial genera, Gemmatimonas, Acidobacterium and Prosthecobacter had high counts at Piegan Pass and at Siyeh Pass. The total number of microbes was greater in green stripes. The percent composition by genera of the microbial community differed between green and brown stripes. While green stripes contained a larger percentage of common soil microbes (17\% as compared to $12.97 \%$ ), brown stripes had a higher percentage (6.98\%) of the thermophilic bacteria Thermacetogenium and Thermoflavimicrobium than green stripes $(3.96 \%, P=0.16)$. In green stripes, the common soil bacteria Gemmatimonas, Acidobacterium and Conexibacter composed the largest number of $16 \mathrm{~S}$ rRNA sequences. The hydrophilic genus Prosthecobacter had 6524 sequences on green stripes as compared to 1183 sequences on brown stripes.

Brown stripes had a higher quantity (expressed as average percent abundance) of thermophilic bacteria composing their microbiome, particularly the heat-loving genera Thermoflavimicrobium and Thermacetogenium. Thermoflavimicrobium was more abundant in brown stripes at $3.7 \%$ of the microbial community, with $2.6 \%$ in the green stripes. Although Thermacetogenum was more abundant in green stripes than brown, it composed $3.3 \%$ of the brown stripe microbiome and $1.4 \%$ of the green.

\section{Discussion}

The climate change-induced retreat of snowfields and glaciers (Fagre et al., 2017) underscores the importance of understanding the influence of climate change on alpine plants at Glacier National Park. The bioclimatic envelope of alpine plants varies with position on periglacial patterned ground (Byrne et al., 2014) as reflected in the distribution of alpine plants, functional traits, and soil microbes.

Alpine plants may influence the distribution of soil microbes and vice-versa (King et al., 2012) and in the Canadian High Arctic, vegetated soil adjacent to patterned ground had a higher microbial biomass and more fungi (González et al., 2014). Soil organic carbon was higher on the vegetated rims than in the less vegetated centers of polygons of the Italian Alps (D'amico et al., 2015). Here, the higher percentage of thermophilic bacteria on brown stripes suggests that they may be warmer than the green and thermal differences may influence plant species distribution.

Patterns of plant cover and species may be perpetuated by differences in nutrients. Soil nutrient storage and mobilization are crucial to the completion of reproductive cycles in the brief alpine growing season (Monson et al., 2006). Nutrients may be influenced by the distribution of the ectomycorrhizal dwarf shrubs, S. arctica and D. octopetala, which is symbiotic with N-fixing Frankia sp. (Clawson et al., 2004; Markham, 2009). Ectomycorrhizal dwarf shrubs as well as the herbaceous, ectomycorrhizal Polygonum vivaparum (Massicotte et al., 1998) of the green and brown stripes, can influence nutrients.

Functional traits are tied to community composition (Venn et al., 2014) although filtered by the timing of snowmelt (Venn et al., 2011; Valles et al., 2017). Snow depth and melting influence alpine plants (Billings and Bliss, 1959) and since at GNP the stripes run perpendicularly to gentler slopes but vertically on steeper slopes, and since there are polygons with finely grained centers (Butler and Malanson, 1989, 1999) these variations may influence 
snowmelt. At GNP patterns may have existed for millennia as relics of larger periglacial patterned ground from Holocene climatic deteriorations (Butler and Malanson, 1999, Elias, 1996). Non-cold related, including biogenic processes may contribute to the development of periglacial landforms (André, 2003). Vegetation contributes to temperature differences between the centers and margins of polygons in northern Alaska and northwestern Canada (Walker et al., 2008), where vascular plants are mainly confined to depressions in hummocks, polygons and areas irrigated by snowmelt (Walker et al., 2002).

Similarities in plant functional traits reflect similar environments, while differences reflect competition (Laughlin et al., 2012). The similar traits of D.octopetala and S.arctica may be important for life on the green stripes. These simple-leaved dicotyledonous ectomycorrhizal dwarf shrubs (chaemophytes) have adventitious roots, serving in anchorage (Cockayne, 1912), lateral expansion and clonality (Klimešová et al., 2012) and D. octopetala's evergreen leaves have increased longevity (Kenzo et al., 2016).

Rare arctic-alpine species were more prevalent on the brown stripes. The substantial underground structures of these species are xeromorphic (Nikolova and Vassilev, 2011) and the compact ground-level clusters of divided leaves in A. jonesii and P. pygmaeum and the microphyllous leaves of $D$. macounii, a cushion plant, may provide protection from overheating. Although E. lanatus was found on both stripes, its taproot and trichome-rich leaves may enhance survival on the brown stripes (Stevanović and Vujnović, 1990), as with Degeniavelebitica, axeromorphic scree plant of Mediterranean mountains.

The importance of xeromorphic traits extends beyond the rare arctic-alpine species to the general pool of species on the brown stripes. Xeromorphic traits may prove instrumental in withstanding the microclimate of the brown stripes (Malanson et al., 2012). Species of the brown stripes can avoid competition.

Clonal mechanisms differed significantly with position on periglacial patterned ground. Colonizing rhizomes have vegetative and floral buds and stores of carbohydrates (Klimešová et al., 2012). Brown stripes are open to colonization and inhabited by the rhizomatous Epilobium anagalidifolium and Oxyria digyna, while green stripes have clonality via the adventitious roots of $D$. octopetala and $S$. arctica. These differences reflect those of Spitsbergen (Klimešová et al., 2012) where rhizomes differed with substrate and hypogeogenous rhizomes were less prevalent on stony ground.

The sensitivity of plant morphology to environmental factors was reflected in the prevalence of hemicryptophytes (Raunkiaer, 1934) on brown stripes and chaemophytes on green stripes. Changes in the abundance and distribution of dwarf shrubs with environmental change are likely to have impacts on alpine communities (Dawes et al., 2011).Cushion morphology may be especially important on the brown stripes, since cushion plant temperatures decouple from the external environment (Larcher and Wagner, 2010). Although leaf temperature of the alpine cushion plant Silene acaulis can exceed ambient temperature by over $20^{\circ} \mathrm{C}$ on calm sunny days (Gauslaa, 1984; Neunerr et al., 2000), cushion plants can overheat (Körner, 2003) and sustain photosystem damage at high temperatures, which is important in terms of climate change (Buchner et al., 2015).

Krummholz of Abies lasiocarpa and Pinus albicaulis on the green stripes are potential seed sources for colonization and establishment of trees on land currently devoid of trees. 
This potential influx of trees can change alpine habitats (Fagre et al., 2003; Resler et al., 2005; Malanson et al., 2007).

Long-term monitoring is important for understanding alpine ecosystems (Mark et al., 2015; Hotaling et al., 2017), and responses of alpine plants to climate change (Gottfried et al. 2012; Pauli et al., 2012). Diverse methods and scales of monitoring can be deployed (Strachan et al., 2016; Hotaling et al., 2017) to study microbial ecology, plant-animal interactions, human impacts, inter-annual variations in snowfall, phenology, and plant functional traits. Individual trees can be visualized remotely (Google Earth, 2017). Fine-scale monitoring can detect changes in plant-specific parameters. In-situ cameras and sensor networks (Strachan et al., 2016) extend monitoring beyond the short summers of physical accessibility.

Georeferenced plots on striped periglacial patterned ground at Glacier National Park are an observatory for long-term monitoring, which is useful in determining and predicting the responses of alpine plants to climate change (Lesica and McCune, 2004), and may protect rare arctic-alpine species from trampling (Price, 1985), especially in light of the record numbers of visitors to GNP (Ouellet 2016) and the propensity of hikers to develop social trails (Wimpey and Marion, 2011). The Glacier National Park observatory can be linked to networks of observatories (Grabherr et al., 2005). Long-term monitoring will likely become increasingly important with elevation-dependent warming (Pepin et al., 2015) and the movement towards mountains without permanent snow and ice due to decreases in the cryosphere because of anthropogenic climate change (Huss et al., 2017).

\section{Conclusion}

To understand current plant and microbial distribution in the changing alpine environment of Glacier National Park, we established long-term geospatially referenced transects on periglacial patterned ground. We surveyed plants and microbes of the flat brown stripes that alternate with the sloping green stripes. Our results demonstrated that plant functional traits differ significantly between the brown and green stripes and that the brown stripes contained a significantly greater proportion of rare arctic-alpine plant species than the green stripes. The predominantly hemicryptophytic plants of the brown stripes had rhizomes and substantial root systems, while the chamaephytic dwarf shrubs of the green stripes formed mats with adventitious roots. Soil microbes of brown stripes had significantly more thermotolerant genera. The differences in plant and microbial distribution point to the importance of microhabitat and thermal differences in stripes of periglacial patterned ground. This knowledge is important in conservation of rare arctic-alpine and other alpine plant species. It is especially important with regards to trail development, decreases in available habitat, and changes in alpine hydrology due to snowfield loss and other aspects of climate change.

\section{Acknowledgements}

We acknowledge the Rocky Mountain-Cooperative Ecosystem Study Unit, Institute on Ecosystems, the Crown of the Continent Research Learning Center at Glacier National Park, Montana Technological University, and the field assistance of Nicky Ouellet, Rene Ouellet, Lindsay Carlson, D.J. Moritz, James Gallagher, and Charlie Apple. 


\section{References}

André M-F, 2003. Do periglacial landscapes evolve under periglacial conditions? Geomorphology, 52(1/2): $149-164$.

Austin M P, 2013. Inconsistencies between theory and methodology: A recurrent problem in ordination studies. Journal of Vegetation Science, 24: 251-268.

Billings W D, Bliss L C, 1959. An alpine snowbank environment and its effects on vegetation, plant development, and productivity. Ecology, 40(3): 388-397.

Björk R G, Molau U, 2007. Ecology of alpine snowbeds and the impact of global change. Arctic, Antarctic, and Alpine Research, 39(1): 34-43.

Brugger K, 2017. World map of the Köppen-Geiger climate classification updated map for the United States of America. Climate Change and Infectious Diseases Group, University of Vienna. http://koeppen-geiger. vu-wien.ac.at/usa.htm.

Buchner O, Stoll M, Karader M et al., 2015. Application of heat stress in situ demonstrates a protective role of irradiation on photosynthetic performance in alpine plants. Plant, Cell, and Environment, 38(4): 812-826.

Bueno de Mesquita C P, King A J, Schmidt S K et al., 2016. Incorporating biotic factors in species distribution modeling: Are interactions with soil microbes important? Ecography, 39: 970-980.

Butler D, Malanson G, 1989. Periglacial patterned ground, Waterton-Glacier International Peace Park, Canada and USA. Zeitschriftfür Geomorphologie, 33: 43-57.

Butler D, Malanson G, 1999. Site locations and characteristics of miniature patterned ground, eastern Glacier National Park, Montana, U.S.A. Landform Analysis, 2: 45-49.

Byrne J M, Fagre D, MacDonald R et al., 2014. Climate change and the Rocky Mountains. Impact of Global Changes on Mountains: Responses and Adaptation, 432.

Cannone N, Guglielmin M, Gerdo R, 2004. Relationships between vegetation and periglacial landforms in northwestern Svalbard. Polar Biology, 27: 562-571.

Carey M, 2007. The history of ice: How glaciers became an endangered species. Environmental History, 12(3): 497-527.

Cavieres L A, Badano E I, Sierra-Almeida A et al., 2007. Microclimatic modifications of cushion plants and their consequences for seedling survival of native and non-native herbaceous species in the High Andes of Central Chile. Arctic, Antarctic, and Alpine Research, 39(2): 229-236.

Choler P, 2005. Consistent shifts in alpine plant traits along a mesotopographical gradient. Arctic, Antarctic, and Alpine Research, 37(4): 444-453.

Clawson M L, Bourret A, Benson D R, 2004. Assessing the phylogeny of Frankia-actinorrhizal plant nitrogen-fixing root nodule symbioses with Frankia 16S rRNA and glutamine synthetase gene sequences. Molecular Phylogenetics and Evolution, 31: 131-138.

Cockayne L, 1912. On the peopling by plants of the subalpine riverbed of the Rakaia (Southern Alps of New Zealand). Transaction of the Botanical Society of Edinburgh, 24(1-4): 104-125.

Cornwall W K, Ackerly D D, 2009. Community assembly and shifts in plant trait distributions across an environmental gradient in coastal California. Ecological Monographs, 79(1): 109-126.

Creese C, Lee A, Sack L, 2010. Drivers of morphological diversity and distribution in the Hawaiian fern flora: Trait associations with size, growth form, and environment. American Journal of Botany, 98(6): 955-966.

Cripps C L, Eddington L E, 2005. Distribution of mycorrhizal types among alpine vascular plant families on the Beartooth Plateau, Rocky Mountains, USA, in reference to larger-scale patterns in Arctic-alpine habitats. Arctic, Antarctic, and Alpine Research, 37: 177-188.

D'amico M E, Gorra R, Freppaz M, 2015. Small-scale variability of soil properties and soil-vegetation relationships in patterned ground on different lithologies (NW Italian Alps). Catena, 135: 47-58. doi: 10.1016/ j.catena.2015.07.005.

Dawes M A, Hagedorn F, Zumbrunn T et al., 2011. Growth and community responses of alpine dwarf shrubs to in situ $\mathrm{CO}_{2}$ enrichment and soil warming. New Phytologist, 191: 806-818. 
De Micco V, Aronne G, 2012. Morpho-anatomical traits for plant adaptation to drought. In: Aroca R (ed.). Plant Responses to Drought Stress. Berlin: Springer, 37-61.

de Witte L C, Stöcklin J, 2010. Longevity of clonal plants: why it matters and how to measure it. Annals of Botany, 106(6): 859-870.

Dvorský M, Chlumská Z, Altman J et al., 2016. Gardening in the zone of death: An experimental assessment of the absolute elevation limit of vascular plants. Scientific Reports, 6. http: doi.org/10.1038/srep24440.

Elias S A, 1996. The ice-age history of national parks in the Rocky Mountains. Washington, DC: Smithsonian Institution Press, 170 pp.

Fagre D B, McKeon L A, Dick K et al., 2017. Glacier margin time series (1966, 1998, 2005, 2015) of the named glaciers of Glacier National Park, MT, USA: U.S. Geological Survey Data Release. https://doi.org/10.5066/ F7P26WB1.

Fagre D B, Peterson D L, Hessl A M, 2003. Taking the pulse of mountains: Ecosystem responses to climatic variability. Chapter in Climate Variability and Change in High Elevation Regions: Past, Present \& Future, pp. 263-282. Volume 15 of the Series Advances in Global Change Research. Berlin, Germany. Springer, 283 pp.

Forbis T A, Doak D F, 2004. Seedling establishment and life history trade-offs in alpine plants. American Journal of Botany, 91: 1147-1153.

Fortunel C, Garnier E, Joffre R et al., 2009. Leaf traits capture the effects of land use changes and climate on litter decomposability of grasslands across Europe. Ecology, 90(3): 598-611.

Garnier E, Lavorel S, Ansquer P et al., 2007. Assessing the effects of land-use change on plant traits, communities and ecosystem functioning in grasslands: A standardized methodology and lessons from an application to 11 European sites. Annals of Botany, 99: 967-985.

Gauslaa Y, 1984. Heat resistance and energy budget in different Scandinavian plants. Holarctic Ecology, 7: 1-78.

González G, Gould W A, Rivera-Figueroa F J et al., 2014. Microorganisms in small patterned ground features and adjacent vegetated soils along topographic and climatic gradients in the High Arctic, Canada. Open Journal of Soil Science, 4(1): 47-55. Doi: 10.4236/ojss.2014.41007.

Google Earth Version 7.1.8 3036, 2017. https:/earth.google.com. 4843’11’N, 113³7’47’W. 4.82 km, Siyeh Pass, Glacier National Park, Montana. March 1, 2018.

Gottfried M, Pauli H et al., 2012. Continent-wide response of mountain vegetation to climate change. Nature Climate Change, 2: 111-115.

Grabherr G, 2003. Alpine vegetation dynamics and climate change: A synthesis of long-term studies and observations. Pp. 399-409. In: Nagy L, Grabherr G, Körner C et al. (eds.). Alpine Biodiversity in Europe. Ecological Studies, 167. Berlin, Germany. Springer, 479 pp.

Grabherr G, Gurung A B, Dedieu J-P et al., 2005. Long-term environmental observations in mountain biosphere reserves: Recommendations from the EU GLOCHAMORE Project. Mountain Research and Development, 25(4): 376-382.

Hall M H P, Fagre D B, 2003. Modeled climate-induced glacier change in Glacier National Park, 1850-2100. Bioscience, 53(2): 131-140.

Hotaling S, Hood E, Hamilton T L, 2017. Microbial ecology of mountain glacier ecosystems: biodiversity, ecological connections, and implications of a warming climate. Environmental Microbiology, 19(8): 2935-2948.

Huss M, Bookhagen B, Huggel C et al., 2017. Toward mountains without permanent snow and ice. Earth's Future, 5: 418-435.

Kade A, Walker D, 2008. Experimental alteration of vegetation on non-sorted circles: effects on cryogenic activity and implications for climate change in the Arctic. Arctic, Antarctic, and Alpine Research, 40(1): 96-103.

Kenzo T, Tanaka-Oda A, Mastuura Y et al., 2016. Morphological and physicochemical traits of leaves of different life-forms of various broadleaf woody plants in interior Alaska. Canadian Journal of Forest Research, 46: 1475-1482.

King A J, Farrer E C, Suding K N et al., 2013. Co-occurrence patterns of plants and soil bacteria in the high-alpine subnival zone track environmental harshness. Frontiers in Microbiology, 4: 239.

Klimešová J, Doležal J, Prach K et al., 2012. Clonal growth forms in Arctic plants and their habitat preferences: A 
study from Petuniabukta, Spitsbergen. Polish Polar Research, 33(4): 421-442.

Kohls S J, Baker D W, van Kessel C et al., 2003. An assessment of soil enrichment by actinorrhizal $\mathrm{N}_{2}$ fixation using $15 \mathrm{~N}$ values in a chronosequence of deglaciation at Glacier Bay, Alaska. Plant and Soil, 254: 11-17.

Körner C, 2003. Alpine Plant Life. Functional Plant Ecology of High Mountain Ecosystems. Berlin, Germany: Springer. 349 pp.

Larcher W, Wagner J, 2010. Temperatures in the life zones of the Tyrolean Alps. Sitzungsberichte Abt., I 213: 31-51.

Laughlin D C, Joshi C, van Bodegom P M et al., 2012. A predictive model of community assembly that incorporates intraspecific trait variation. Ecology Letters, 15: 1291-1299.

Lesica P, 2002. Flora of Glacier National Park. Corvallis, Oregon. Oregon State University Press, 512 pp.

Lesica P, 2012. Manual of Montana Vascular Plants. Austin, Texas. Botanical Research Institute of Texas. 779 pp.

Lesica P, 2014. Arctic-alpine plants decline over two decades in Glacier National Park, Montana, U.S.A. Arctic, Antarctic, and Alpine Research, 46(2): 327-332.

Lesica P, McCune B, 2004. Decline of arctic-alpine plants at the southern margin of their range following a decade of climatic warming. Journal of Vegetation Science, 15: 679-690.

Li H, Nicotra A B, Danghui X et al., 2015. Habitat-specific responses of leaf traits to soil water conditions in species from a novel alpine swamp meadow community. Conservation Physiology, 3(1): 1-8.

Malanson G P, Bengtson L E, Fagre D B, 2012. Geomorphic determinants of species composition of alpine tundra, Glacier National Park, U.S.A. Arctic, Antarctic, and Alpine Research, 44(2): 197-209.

Malanson G P, Butler D R, Fagre D B et al., 2007. Alpine treeline of western North America: Linking organism-to-landscape dynamics. Physical Geography, 28(5): 378-396.

Mark A F, Korsten A C, Urrutia Guevara D et al., 2015. Ecological responses to 52 years of experimental snow manipulation in High-Alpine Cushionfield, Old Man Range, South-Central New Zealand. Arctic, Antarctic, and Alpine Research, 47(4): 751-752. doi.org/10.1657/AAAR0014-098.

Markham R, 2009. Does Dryas integrifolia fix nitrogen? Botany, 87(11): 1106-1109.

Massicotte H B, Melville L H, Peterson R L et al., 1998. Anatomical aspects of field ectomycorrhizas on Polygonum viviparum (Polygonaceae) and Kobresiabellardii (Cyperaceae). Mycorrhiza, 7(6): 287-292.

Matthews J A, Shakesby R A, Berrisford M S et al., 1998. Periglacial patterned ground on the Styggedalsbreen glacier foreland, Jotunheimen, southern Norway: Micro-topographic, paraglacial and geoecological controls. Permafrost and Periglacial Processes, 9(2): 147-166.

McGill B J, Enquist B J, Weiher E et al., 2006. Rebuilding community ecology from functional traits. Trends in Ecology and Evolution, 21(4): 178-185.

Monson R K, Rosenstiel T N, Forbis T A et al., 2006. Nitrogen and carbon storage in alpine plants. Integrative and Comparative Biology, 46(1): 35-48.

Mouillot D, Graham N A J, Villéger S et al., 2013. A functional approach reveals community responses to disturbances. Trends in Ecology and Evolution, 28(3): 167-177.

Neuner G, Buchner O, Braun V, 2000. Short-term changes in heat tolerance in the alpine cushion plant Silene acaulis ssp. excapa [All.] J. Braun at different altitudes. Plant Biology, 2: 677-683.

Nikolova A, Vassilev A, 2011. A study on Tribulus Terrestris L. Anatomy and ecological adaptation. Journal of Biotechnology and Biotechnological Equipment, 25(2): 2369-2372.

Ouellet N, 2016. Record Numbers Visit Glacier National Park in 2016. Montana Public Radio. http://mtpr.org/post/record-numbers-visit-glacier-national-park-2016.

Pauli H, Gottfried M, Dullinger S et al., 2012. Recent plant diversity changes on Europe's mountain summits. Science, 336(6079): 353-355.

Pederson G T, Graumlich L J, Fagre D R et al., 2010. A century of climate and ecosystem change in Western Montana: What do temperature trends portend? Climate Change, 98(1): 133-154.

Pepin N, The Mountain Research Initiative EDW Working Group, 2015. Elevation-dependent warming in mountain regions of the world. Nature Climate Change, 5: 424-430.

Pérez-Harguindeguy N, Diaz S, Garnier E et al., 2013. New Handbook for Standardized Measurement of Plant Functional Traits Worldwide. Australian Journal of Botany, 61: 167-234. 
Price M F, 1985. Impacts of recreational activities on alpine vegetation in Western North America. Mountain Research and Development, 5(3): 263-278.

Raunkiær C C, 1934. The Life Forms of Plants and Statistical Plant Geography. Oxford University Press, pp. 632.

Resler L M, Butler D R, Malanson G P, 2005. Topographic shelter and conifer establishment and mortality in an alpine environment, Glacier National Park, Montana. Physical Geography, 26(2): 112-125.

Scherrer D, Körner C, 2011. Topographically controlled thermal-habitat differentiation buffers alpine plant diversity against climate warming. Journal of Biogeography, 38: 406-416.

Sonneman I, Pfestorf H, Jeltsch F et al., 2015. Community-weighted mean plant traits predict small scale distribution of insect root herbivore abundance. PLOS One, http://dx.doi.org/10.1371/journal.pone.0141148.

Stevanović B Vujnović K, 1990. Morpho-anatomical adaptations of the endemic species Degeniavelebitica (DEG.) HAY. Feddes Repertorium, 101(7/8): 385-389.

Strachan S, Kelsey E P, Brown R F et al., 2016. Filling the data gaps in mountain climate observatories through advanced technology, refined instrument siting, and a focus on gradients. Mountain Research and Development, 36(4): 518-527.

Tobias T B, Farrer E C, Rosales A et al., 2017. Seed-associated fungi in the alpine tundra: Both mutualists and pathogens could impact plant recruitment. Fungal Ecology, 30: 10-18.

Valles D, Apple M E, Andrews C, 2017. Visual simulations correlate plant functional trait distribution with elevation and temperature in the Cairngorm Mountains of Scotland. International Conference on Computational Science and Computational Intelligence, 17: 1252-1258. doi: 10.1109/CSCI.2017.220.

Venn S E, Green K, Pickering C M et al., 2011. Using plant functional traits to explain community composition across a strong environmental filter in Australian alpine snowpatches. Plant Ecology, 212: 1491-1499.

Venn S E, Pickering C M, Green K, 2014. Spatial and temporal functional changes in alpine summit vegetation are driven by increases in shrubs and graminoids. AoB Plants, 6: plu008. doi: 10.1093/aobpla/plu008.

Vitasse Y, Rebetez M, Filippa G et al., 2016. 'Hearing' alpine plants growing after snowmelt: ultrasonic snow sensors provide long-term series of alpine plant phenology. International Journal of Biometeorology, 61(2): 349-361.

Walker D A, Epstein H E, Romanovsky V E et al., 2008. Arctic patterned-ground ecosystems: A synthesis of field studies and models along a North American Arctic Transect. Journal of Geophysical Research: Biogeosciences, 113(G3): G03S01. doi: 10.1029/2007JG000504.

Walker D A, Gould W A, Maier H A et al., 2002. The Circumpolar Arctic Vegetation Map: AVHRR-derived base maps, environmental controls, and integrated mapping procedures. International Journal of Remote Sensing, 23(21): 4551-4570.

Wimpey J, Marion J L, 2011. A spatial exploration of informal trail networks within Great Falls Park, VA. Journal of Environmental Management, 92(3): 1012-1022. 